borings surrounded by fossiliferous sand, just as described by Mr. T. Mellard Reade from the Lancashire area. These stones are generally limestones of various kinds-Carboniferous, Magnesian, Jur issic, or Cretacesus - and the diversity of their origin seems to show that they have first been scattered over a shallow seahottom by floating ice, and afterwards perforated, but I do not think that they can be taken as proof of the marine origin of the bould $\mathrm{r}$ clay in which they now lie.

The same boulder clay contains many detached valves of bivalve shells, and these very frequently still hold a pinch of sand under the umbo, though themselves firmly embedded in hard clay; and in one case I found, under such conditions, a perfect shell (Tellina balthica), with valves united, enclosing similar sandy material.

It seenis to me very difficult to explain by any theory of floating ice how this sandy matrix could have been preserved in the holes of the stones and under the valves of the shells, while it is easy to understand how this might take place tbrough the agency of land ice advancing over a sea-bottom.

Before the culmination of the glacial period, while yet the ice was encroaching upon the sea-bed, and long before it had reached its greatest extension, there must have heen a vast quantity of floating ice in the waters, which would drop stones and other material over the sea-bottom; and there must also have been a great extrusion of matter from the varions glaciers. And as the ice advanced this material would necessarily become part of the moraine profonde of the glacier, and would be more or less mixed up with the old sea-bottom, but the resulting boulder clay could scarcely be called marine.

Bridlington Quay, July I5.

\section{Mr. Lydekker on Phenacodus and the Athecæ.}

IN his article on Phenacodus primbevus in NATURE of May r6 (p. 57), Mr. Lydekker expresses his disbelief in my opinion that that animal is nearly related to the immediate ancestor of the line of the Quadrumana, and of man. I am somewhat surprised at the positiveness of Mr. Lydekker's expression, as he must be aware of the difficulties that still surround this part of the question. What may be known about it is as follows :-

First, I have always been careful to avoid the assertion that the genus Phenacodus was in the direct line of descent of man. When I first traced the ancestry of the Quadrumana, I indicated the sub-order Condylarthra as its source (American Naturalist, 1885, p. 347 ; "Origin of the Fittest," I 887, p.343), not the genus Pheracodus. On a subsequent occasion I restricted the range of probable ancestry to the family Phenacodontidle (Naturalist, I888, p. 663). In the advertisement to which Mr. Lydekler refers, I say of the Phenacodus primnezus, "Representative of type believed to be the ancestor of all hoofed Mammalia, monkeys, and man." Mr. Lydekker's reference to this advertisement is slightly different.

Second, Mr. Lydekker objects to regarding Phenacodus as within the ancestry of the lemurs and man, because it appears to have no clavicle. To this proposition two replies may be made. The first is, that it is by no means certain that it had no clavicle. The second is, that if it had none it is not certain that that fact would exclucle it from the ancestry of the Quadrumana; certainly it would not exclude some near ally of the same family or sub-order which possessed a clavicle. On these points I remark further.

Third, nothing can be determined from the specimens as to whether the Phenacodus primevus or P. zuortmani had clavicles or not. None were found, but this part of the skeleton was disturbed in both specimens. Thus the clavicles, if present, may have been like those of some Carnivora and Rodentia, connected with the manubrium sterni and scapula by soft tissue only, and so have been readily lost.

Fourth, the presence or absence of clavicles is not important in a systematic sense. It is not available as a definition in the orders Edentata, Rodentia, Insectivora, and Carnivora, where, as is well known, it may be present, rudimental, or absent. And in the phylogenetic history of a line, I see no reason why clavicles might not lose and later recover their osseous tissue under suitable stimulation.

Finally, I believe that the Condylarthra are in the direct line of ancestry of the higher apes, so long as no better objections can be found than those raised by Mr. Lydekker. Another objection exists which he has not pointed out; viz. the absence of anapophyses of the vertebræ. But this objection loses much woi ', when we remember that anapophyses are also wanting from the vertebre of the anthropoid apes and man. What their status was in the anthropoid lemurs (Anaftomorphus) we do not yet know. Moreover, a trace of the anapophysial structure does exist in both species of Phenacodus, as a fold continuous from the posterior border of the neural arch over the centrum. As regards the clavicle, it is highly probable that it is present in some of the genera of the Condylarthra, and even of the Phenacodontida, such, for instance, as Protogonia, but we know too little of the structure of the skeletons of several allied genera, to enable us to determine the points in question. On the presence or absence of anapophyses in such genus of Condylarthra will depend the solution of the question whether the descent of man passes through Anaptomorphus or Adapis, or some other undiscovered form of Quadrumana, to the anthropoid apes.

While on this subject I refer to Mr. Lydekker's reference to my term Athecæ (Testudinata), as " ungrammatical." He de clares that the grammatical form should be Athecata. Now, while the latter expression is perbaps grammatical, it is not more so than the one which I elected to use. It -is probably well known to Mr. Lydekker that scientific names are written in Latin, and not in Greek. The singular Atheca, although derived from the Greek, becomes Latin by scientific use and usage, and is declined, genitive $a$, and nominative plural $a$ also. See Latin words derived from $\theta \dot{\eta} \kappa \eta$, as Bibliotleca, $-x$. I used the substantive form, which is more usual than the adjective, in making scientific names.

Philadelphia, July $\mathrm{I}$.

\section{Systematic Position of the Characex.}

THE position in a natural system of classification of this small and strongly-differentiated group of aquatic plants has been so long a subject of controversy, that any additional light upon it will be welcome to vegetable physiologists. I therefore desire to call the attention of my fellow-botanists to the remarkable paper by M. Guignard, "On the Development and Constitution of the Antherozoids of Cryptogams," in the early numbers of the new hotanical journal edited by M. Bonnier-the Revue Générale de Botanique. It is true that these observations only confirm the earlier ones of Thuret; but the care with which M. Guignard has worked out the subject, and his beautiful drawings, tend to emphasize the results previously obtaintd.

No one who compares the drawings of the antherozoid of Char fragilis in Pl. 2 with those of Fellia epiphliylla in Pl. 3 can fail to be struck with their remarkable resemblance. Each is a long, corkscrew.shaped body, with a pair of very long and slender vibratile cilia attached to its anterior extremity. The mode of development of the antherozoid is also the same in all essential particulars in both cases, and is thus described by M. Guignard. The body of the antherozoid proceeds from the nucleus of the mother-cell, and moreover gives all the micro-chemical reactions of nuclein. The vibratile cilia are derived from the cytoplasm. A thickening band first appears on the surface of the nucleus, and grows longer and longer, forming eventua!ly a kind of beak, and the whole nucleus becomes twisted spirally as it increases in length. As soon as the outlines of the anterior extremity of the filament are discernible, the two cilia may be perceived in the thin layer of hyaline protoplasm which is nearest this extremity. Later on, the cilia, which at first lie close to the filament, become separated from it, and the rest of the protoplasm gradually disappears, being absorbed and used up for the nutrition of the antherozoid, so that only a few granulations are left on the posterior extremity of the filament. The only difference of any importance between the antherozoids of Characer and those of Muscinere is the absence in the former of a vesicle formed from the cytoplasm of the mother-cell.

If now this is compared with the figures (Pl. 5) of the antherozoids of Fucus scrratus, and the account of their mode of development, it will be seen how wide are the differences in many essential points between the cornesponding processes in Characere and in the higher Algre. These facts seem to me strongly to corroborate the view which I have on several occasions ventured to bring forward, and to support by other considerations, that the Characeæ are more nearly related to the Muscinex than to the true Algx.

I may mention in conclusion that $\mathrm{M}$. Guignard adopts the revised terminology which I have advocated, of antherozoi, instead of "spermatozoid" for the male fecundating organs of most Cryptogams, and of pollinoids (or rather pollinites) instead of "spermatia" for the corresponding organs in the Florideæ. AlFred W. Bennett. 